\title{
Apendektomi Yapılan Gebe Olgularda Anestezi Yönetimi
}

\author{
Anesthetic Management of Pregnant Patients Undergoing Appendectomy \\ Gözen ÖKSÜZ ${ }^{1}$, Gökçe GISŞİ ${ }^{1}$, Aykut URFALIOĞLU ${ }^{1}$, Mahmut ARSLAN ${ }^{1}$ \\ Şeyma TEKŞEN ${ }^{2}$, Ömer Faruk BORAN ${ }^{1}$, Hafize ÖKSÜZ ${ }^{3}$
}

1. Sütçü Imam Üniversitesi Tıp Fakültesi, Anesteziyoloji ve Reanimasyon ABD. Kahramanmaraş, Türkiye, Yard. Doç. Dr. 2. Sütçü Imam Üniversitesi Tıp Fakültesi, Anesteziyoloji ve Reanimasyon ABD. Kahramanmaraş, Türkiye, Arş. Görevlisi 3. Sütçü Imam Üniversitesi Tıp Fakültesi, Anesteziyoloji ve Reanimasyon ABD. Kahramanmaraş, Türkiye, Prof. Dr.

\section{$\ddot{O Z Z E T}$}

Amaç: Her yıl gebe kadınların \%1-2 si gebelik dışı nedenlerle operasyon geçirir. Gebelik esnasında en sik gebelik dişı cerrahi müdahaleye gerek duyulan hastalık apandisittir. Gebede gelişen fizyolojik değişiklikler nedeniyle cerrahi ve anestezi prosedürlerine cevap anne ve fetüs açısından riskler içerir. Biz bu çalıșmada gebelik sirasında obstetrik dıș cerrahi müdahale için en uygun anestezi yönetimini ve komplikasyonlar açısından dikkat edilmesi gerekenler etkenleri incelemeyi hedefledik.

Materyal ve Metod: Ocak 2012- Eylül 2015 yılları arasında hastanemize başvuran gebe olup apandisit teşhisi konulan hastalar retrospektif olarak incelendi. Hastaların anestezi yöntemleri, anestezi yönetimi, fetal ve maternal komplikasyonlar kaydedildi.

Bulgular: Kayttlar incelendiğinde 2012 ocak ve 2015 eylül tarihleri arasında gebe olup karın ağrisı ile hastaneye bașvuran ve apandisit teşhisi alan 19 hasta olduğu gözlendi.19 hastanin 17 tanesine apendektomi operasyonu yapılmış olduğu görüldü. Apendektomi yapılan olgularin 4 tanesine spinal anestezi yapul-

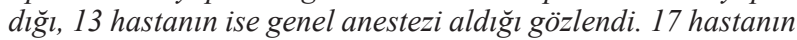
16 sında anne ve bebek açısından sorun çıkmazken 31 haftalık gebeliği olan bir olgunun 4 gün sonra preterm eylem nedeniyle sezaryana alındiğl ve sağllkl bir bebek dünyaya getirdiği kayıtlardan anlaşıldl. 17 hastanın bir tanesinin 37 hafta gebelik strasinda apandisit tanisiyla genel anestezi altında sezaryana alındiğ $\mathrm{v}$ ve sezaryan sonrasinda apendektomi operasyonunun yapılmış olduğu görüldü.

Sonuc: Gebe hastalarımızda gebelik disl cerrahi gerektiğinde anne ve fetüs açısından komplikasyonları önlemek için hazırlıkların ve değerlendirmenin çok iyi yapılması anne ve bebeğin perioperatif ve postoperatif çok iyi takip edilmesi gerekmektedir.

Anahtar Kelimeler: gebe, anestezi, apendektomi

\section{ABSTRACT}

Objective: Every year, 1-2\% of pregnant women undergo non-obstetric surgery. Appendicitis is the most frequent non-obstetric disease requiring surgery during pregnancy. Because of the physiological changes of pregnancy, response to surgical and anesthetic procedures carry risks for mother and fetus. In this study, we aimed to investigate the most appropriate anesthetic technique for management of non-obstetric surgery and the factors that should be considered in terms of complications.

\section{İletişim Bilgiler}

Sorumlu Yazar: Gözen ÖKSÜZ, Yard. Doç. Dr.

Yazışma Adresi: Kahramanmaraş Sütçü İmam Üniversitesi Tıp Fakültesi, SAU Hastanesi, Anesteziyoloji ve Reanimasyon ABD. Avşar Kampüsü, Onikişubat, Kahramanmaraş, TÜRKiYE E-posta: gozencoskun@gmail.com

Tel: +90 (344) 3803257 Mobil: +90 (505) 6032953

Makale Geliş Tarihi: 21.08.2017

Makale Kabul Tarihi: 17.09.2017

DOI: http://dx.doi.org/10.16948/zktipb.335546
Material and Method: Pregnant patients diagnosed with appendicitis between January 2012 and September 2015 were retrospectively investigated. Anesthetic techniques, anesthetic management, fetal and maternal complications were recorded.

Results: In hospital records between January 2012 and September 2015, 19 patients were diagnosed with appendicitis among pregnant patients who referred to the hospital with abdominal pain. 17 patients had appendectomy. Four of the appendectomy cases were operated under spinal anesthesia and 13 patients were operated under general anesthesia. In 16 patients, no maternal or fetal complication was observed. One patient who had appendectomy under general anesthesia at 31 weeks of gestation underwent caesarean section 4 days after surgery because of preterm labor and a healthy baby was born. One out of 17 cases with appendectomy was at 37 weeks of gestation and she has appendectomy after caesarean delivery.

Conclusion: When non-obstetric surgery is needed in pregnant patients, to prevent maternal and fetal complications preoperative preparation and evaluation should be done properly and mother and fetus should be observed closely in the perioperative and postoperative period.

Keywords: pregnant, anesthesia, appendectomy

"Apendektomi Yaptlan Gebe Hastalarda Anestezi Yönetimi" isimli yazımız 2016 TARK Antalya ulusal kongresinde poster olarak sunulmuştur.

\section{GíRiş}

Her yıl gebe kadınların \%1-2'si gebelik dışı nedenlerle operasyon geçirir. Apendektomiler bu operasyonların yaklaşık \%25'i oluşturur. Gebelik esnasında en sık gebelik dişı cerrahi müdahaleye gerek duyulan hastalik apandisittir. Gebeliğin semptomlarından bulantı, karın ağrısı, kabızlık gibi benzer şikayetler nedeniyle apandisit tanıs1 gecikebilir (1). Gebede gelişen fizyolojik değişiklikler nedeniyle cerrahi ve anestezi prosedürlerine cevap anne ve fetüs açısından riskler içerir. Gebelikte ilk trimester teratojenite açısından, üçüncü trimester preterm eylem açısından riskli görülürken en güvenli trimester 2. trimesterdır (2).

Apendektomi cerrahi olarak laparoskopik ve açık cerrahi şeklinde, anestezi yöntemi olarak genel ve spinal anestezi altında yapılır (3). Biz bu çalışmada gebelik sırasında obstetrik dışı cerrahi müdahale için en uygun anestezi yönetimini ve komplikasyonlar açısından dikkat edilmesi gerekenler etkenleri incelemeyi hedefledik. 


\section{MATERYAL ve METOD}

$\mathrm{Bu}$ çalışmada üniversite etik kurulundan onay (2016/07-02) alındıktan sonra Ocak 2012Eylül 2015 yılları arasında hastanemize başvuran gebe olup apandisit teşhisi konulan hastalar retrospektif olarak incelendi. Hastaların anestezi yöntemleri, anestezi yönetimi, fetal ve maternal komplikasyonlar kaydedildi.

\section{BULGULAR}

Kayıtlar incelendiğinde 2012 ocak ve 2015 eylül tarihleri arasında gebe olup karın ağrısı ile hastaneye başvuran ve apandisit teşhisi alan 19 hasta olduğu gözlendi.19 hastanın dördünün 3 . trimester, sekizinin 2. trimester ve yedi hastanın 1. trimesterde apandisit teşhisi aldığ 1 tespit edildi. 19 hastanın 17 tanesine apendektomi operasyonu yapılmıș olduğu kayıtlardan görüldü. Onaltı hastaya açık apendektomi operasyonun yapıldığı, bir hastanın laparoskopik cerrahi ile ameliyat edildiği anlaşıldı. Apendektomi yapılan olguların 4 tanesine oturur pozisyonda 27 gauge spinal iğne ile 10-12 mg heavy marcain verilerek spinal anestezi yapıldığı, 4 olgunun hiçbirinde tansiyon ve hemodinamik bulgularda önemli bir değişiklik görülmediği kayıtlardan görüldü. 13 hastanın ise $2-3 \mathrm{mg} / \mathrm{kg}$ propofol, $0.6 \mathrm{mg} / \mathrm{kg}$ rokuronyum verilerek entübe edildiği ve genel anestezi alan hastaların sorunsuz ekstübe edilmiş olduğu gözlendi.

Bütün gebelerin, operasyon sirasinda EKG, $\mathrm{spO}_{2}$, NIBP, nabiz monitorizasyonu ile takip edildiği preoperatif ve postoperatif fetal kalp atımlarının kontrol edildiği görüldü. 16 olguda operasyon sonrasında anne ve fetüs aç1sından sorun olmadığ 1 ve apendektomi yapılan 31 haftalık gebeliği olan bir olgunun 4 gün sonra preterm eylem nedeniyle sezaryana alınarak sağlıklı bir bebek dünyaya getirdiği kayıtlardan anlaşıldı. 17 olgudan bir tanesinin 37 hafta gebelik sırasında apandisit tanısıyla genel anestezi altında sezaryana alındığ 1 sezaryan sonrasında apendektomi operasyonunun yapıldığ 1 anlaşı1di.

\section{TARTIŞMA}

Hastanemize başvuran ve apandisit teşhisi alan gebeler incelendiğinde gebelerin en sik ikinci trimesterde olduğu gözlendi. Literatürü incelediğimizde gebelik sırasında gebelik dış1 operasyonların en sik üçüncü trimesterde olduğunu bildiren çalışmalar olduğu görülmüştür $(4,5)$. Çok sayıda çalışma olmaması ve bizim çalışmamızda hasta profili olarak sadece apandisit tanıs1 alan hastaların incelenmesi ve hasta sayısının az olması nedeniyle bu farklılığın görülebileceğini düşündük. Gebelik sırasında obstetrik dişında nedenlerle operasyon gerekli görüldügünde anestezi ve cerrahi açıdan en güvenli period 2. trimester olduğu belirtilmiştir.

İlk trimesterde anestezinin teratojen etkileri bizim için ön planda olduğu görülürken üçüncü trimesterde anestezinin veya cerrahinin erken doğum eylemini tetikleyebileceği düşünülür (6). Hastanemizde apendektomi yapilan gebe hastalar kayıtlardan incelendiğinde 31 haftalık olan 3. trimesterde bulunan 1 gebede erken doğum eylemi gerçekleşmiştir.

Kayitlardan hastanemize apandisit nedeniyle başvuran ve apendektomi geçiren gebelerin 13 tanesine genel anestezi yapılmış olduğunu gördük. Hastaların 4 tanesine spinal anestezi yapılmıştı. Anestezi yöntemi olarak genellikle rejyonel anestezi önerilmekle beraber bizim çalışmamızda genel anestezinin daha sik uygulandığı kayıtlardan anlaşılmıştır.

Gebelik sırasında apandisit teşhisi gecikebilmekte veya gebelikle ilgili semptomlar nedeniyle atlanabilmekte bu durum apandisit teşhisi konulduğunda perfore olmuş olma ihtimalini artırmaktadır (7). Perforasyon beklenmesi veya tanidan emin olunmamasi anestezi yönetimi açısından hastanemizde opere olan gebe apendektomilerin sayı olarak çoğunun genel anestezi altında opere olmasını açıklamaktadır.

Kayıtlar incelendiğinde opere olan 17 gebenin bir tanesinde preterm eylem gerçekleșerek 4 gün sonra 31 haftalıkken sezaryene alındığ 1 ve sağlıklı bir bebek dünyaya getirdiği görüldü. Hastanın genel anestezi altında açık cerrahi ile apendektomi olduğu kayıtlardan anlaşıldı. Spinal anestezi olan gebelerde herhangi bir komplikasyon gelişmediği ve 4 bebeğin de miadında dünyaya geldiği kayıtlardan tespit edildi.

Gebelik sırasında yapılan cerrahi tipi ve uygulanan anestezi yönetimi şüphesiz anne ve bebek için önem arz etmektedir. Gebelikte mukozal ödemin artması, kilo artışı ve ödem nedeniyle zor entübasyon riskini ve girişimler sırasında kanama ihtimalini arttırır. Artmış aspirasyon riski ve uzamış boşaltım zamanı nedeniyle açl1k süresi anestezi yöntemi açısından değerlendirilmelidir. Annede gelişebilecek hipoksi uterusta vazokonstrüksiyona neden olarak fetüs de hipoksemi ve asidozis görülmesi fetüsün ölümüne yol açar (8).

Özellikle 1. trimesterde genel anestezi uygulanacaksa anestezik ilaçların teratojenik etkilerinden korunmak gerekir. İlaçların plasentadan geçisi fetal asfiksiye ve preterm eyleme neden 
olabilir. Azot protoksit dişındaki genel anestezi ilaçlarının teratojen etkileri gösterilmemiştir. Azot protoksitin megaloblastik anemi yaptığ 1 hayvan deneylerinde belirtilmiştir (7).

Rejyonel anestezi açısından gebeliğe bağlı zorluklar vardır. Rejyonel anestezi yaparken epidural alanın kanlanmasının artığı ve DVT profilaksisi yapılmış olabileceği göz önünde bulundurulmalidır. Ayrıca epidural boşluğun azaldığı düşünülüp kullanılacak lokal anesteziğin dozu ayarlanmalıdır. Anestezistler anne ve fetüs için en güvenli yöntemi uygulamalıdır (8). Hastanemize gelen apendektomi yapilan gebelerde anestezi yöntemini seçerken gebelerin ve 1. Derece yakınlarının onamlarının aldığı görüldü. Anestezi yöntemi seçimi yapılacağında anneye genel ve rejyonel anestezinin tüm riskleri ve avantajları anlatılmalı ayrıca teratojenite ihtimalinden bahsetmek gerekmektedir.

Cerrahi girişim ve anestezi nedeniyle annede gelişebilecek hipoksi, hipovolemi, hipotansiyon, asidoz ve fizyolojik değişiklikler düşüğe, erken doğuma, düşük ağırlıklı doğuma yol açabilir (8).

Kliniğimizde yapılan gebe apendektomi hastaların kayitlarından preoperatif ve postoperatif fetal kalp hızının monitorize edildiği, fetüsün sağlıklı olduğunun değerlendirilip not edildiği kayıtlardan anlaşıldı. Gerek genel gerek spinal anestezide fetüsün sağlığını değerlendirmek için preoperatif münkünse operasyon boyunca ve mutlaka operasyon sonunda fetal kalp atımı monitorize edilmelidir. Transabdominal Doppler aracılığıyla sürekli fetal kalp hızı (FKH) monitörizasyonu gebeliğin 18. haftasından sonra uygulanabilir. FKH değişiklikleri görüldügünde annenin oksijenasyonu düzeltilmeli, kan basincı düşüklüğü mevcutsa yükseltilmeli, uterusun sola deviasyonu sağlanmalıdır. Rejyonel anestezi en az FKH değişikliği sağlamaktadır $(9,10)$.

Anestezi yönetimini sırasında gebelikte görülen fizyolojik değişiklikleri göz önünen alarak riskleri artırmayacak şekilde önemler alınmalıdır. Gebenin solunum sisteminde dakika ventilasyon volümü ve oksijen tüketimi, supin ve trendelenburg pozisyonda hipoksemi riski artar. Gebelikte kardiovasküler sistemde de kardiak output \%50 den fazla artarken uterus perfüzyonu da artar ve bu nedenle rejyonel ve genel anestezi altında hipotansiyon riski artar. 13 haftadan sonra aortakaval kompresyon gelişebileceğinden supin hipotansif sendromdan korunmak için hastaya sol lateral eğim pozisyonu vermek gerekir. Gebede dilüsyonel anemi gelişir ve tromboembolitik olaylarda artma meydana gelir. $\mathrm{Bu}$ nedenle operasyon geçiren gebelere DVT profilaksisi gerekir. Glukozüri ve proteinüri varlığı bilinmeli ve renal fonksiyonlar değerlendirilmelidir $(11,12)$.

Gebelik esnasında gebelik dışı nedenlerle operasyonlar sıklıkla karşılaşabileceğimiz durumlardır. Biz hastanemiz kayıtlarından geriye dönük olarak apendektomi geçiren hastaları inceledik. Gebelerin apendektomi dişında kolesistektomi, over torsiyonu ve inkarsere fitik gibi acil operasyonlar nedeniyle anestezi almaları gerekebilmektedir. Anestezi seçiminde ve yönetiminde aynı hazırlıkların ve değerlendirilmenin yapılması gerekmektedir (13).

\section{SONUÇ}

Gebelik sırasında gebelikle ilişkili olmayan nedenlerle yapılan ameliyatlar için anestezi vermemiz gerektiğinde rejyonel ve genel anestezik ilaçları güvenle kullanabilmemize rağmen bütün riskleri bertaraf etmemiz mümkün gözükmemektedir. Bu nedenle gebe hastalarımızda gebelik dışı cerrahi gerektiğinde hazırlıkların ve değerlendirmenin çok iyi yapılması anne ve bebeğin perioperatif ve postoperatif çok iyi takip edilmesi gerekmektedir.

\section{KAYNA KLAR}

1. Naughton NN, Cohen SE. Nonobstetric surgery during pregnancy. En: Chestnut DH, editor. Obstetric anesthesia: Principles and practice. 3rd ed. Philadelphia: Elsevier Mosby; 2004: 255-72.

2. Hegewald MJ, Crapo RO. Respiratory physiology in pregnancy. Clin Chest Med 2011; 32: 1-13.

3. Van De, Velde M, De Buck F. Anesthesia for non-obstetric surgery in the pregnant patient. Minerva Anestesiol 2007; 73: 235-40.

4. Visser BC, Glasgow RE, Mulvihill KK, Mulvihill SJ. Safety and timing of nonobstetric abdominal surgery in pregnacy. Dig Surg. 2001; 18: $409-17$.

5. Gilo NB, Amini D, Landy HJ. Appendicitis and cholecystitis in pregnancy. Clin Obstet Gynecol 2009; 52: 586-96.

6. Cheek TG, Baird E. Anesthesia for nonobstetric surgery: maternal and fetal considerations. Clin Obstet Gynecol 2009; 52: 535-45.

7. Al-Qudah MS, Amr M, Sroujieh A, Issa A. Appendectomy in pregnancy: the experience of a university hospital. J Obstet Gynaecol 1999; 19: $362-4$

8. Kuczkowki KM. Nonobstetric surgery in the paturient anesthesic consideration. J Clin Anesth 2006; 18: 5-7.

9. Fanzago E. Anesthesia for nonobstetric surgery in pregnant patients. Minerva Anestesiol 2003; 69: 416-27.

10. ACOG Committee on obstetric practice. Guidelines for diagnostic imaging during pregnancy. Obstet Gynecol 2004; 104: 647-51.

11. Barron WM. Medical evaluation of the pregnant patient requiring non-obstetric surgery. Clin Perinatol 1985; 12: 481-96.

12. Bajwa SJ, Bajwa SK. Anaesthetic challenges and management during pregnancy: Strategies revisited Anesth Essays Res 2013; 7: 160-7.

13. Goodman S. Anaesthesia for nonobstetric surgery in the pregnant patient. Semin Perinatol. 2002; 26: 136-45. 